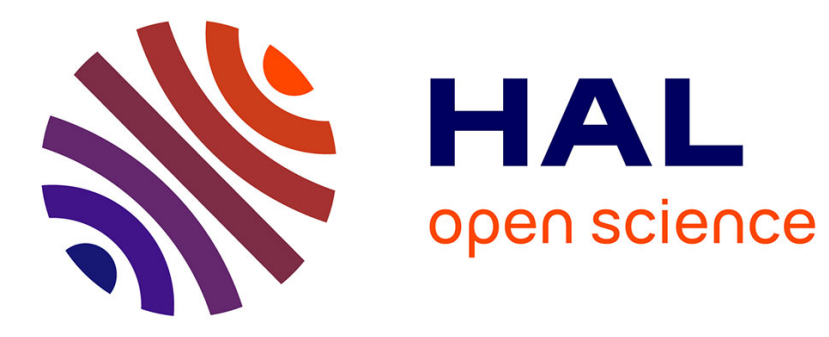

\title{
The Decisive Moment in Mythology: The Instant of Metamorphosis
}

Françoise Letoublon

\section{To cite this version:}

Françoise Letoublon. The Decisive Moment in Mythology: The Instant of Metamorphosis. Anton Bierl, Menelaos Christopoulos, Athina Papachrysostomou. Time and Space in Ancient Myth, Religion and Culture, 10, De Gruyter, pp.335-353, 2017, MythosEikonPoiesis, 978-3-11-053515-0. 10.1515/9783110535150-021 . hal-01919971

\section{HAL Id: hal-01919971 \\ https://hal.univ-grenoble-alpes.fr/hal-01919971}

Submitted on 12 Nov 2018

HAL is a multi-disciplinary open access archive for the deposit and dissemination of scientific research documents, whether they are published or not. The documents may come from teaching and research institutions in France or abroad, or from public or private research centers.
L'archive ouverte pluridisciplinaire HAL, est destinée au dépôt et à la diffusion de documents scientifiques de niveau recherche, publiés ou non, émanant des établissements d'enseignement et de recherche français ou étrangers, des laboratoires publics ou privés. 
The decisive moment in mythology : the instant of metamorphosis

Françoise Létoublon ${ }^{1}$

University of Grenoble-Alpes

\begin{abstract}
We analyze the process of metamorphosis in Greek 'mythographers' as the 'decisive moment" when a person is transformed. We begin with examples drawn from Antoninus Liberalis for showing the role of verbal aspect in the narrative, then some devices of metamorphosis, such as the wand and the touch by a god. Disappearing appears as a form of metamorphosis. The study of the 'instant before' shows the importance of pursuit and impossible flight.

Incestuous loves appear in Antoninus Liberalis, but with more frequency in Parthenius of Nicaea, which allows to imagine that Freud could have found benefit studying these texts for his theory, especially with the narrative of Periandros' mother and the expression of pleasure felt by the son in the relation with his mother (he does not know then who she is). We analyze the kinship between metamorphosis and metaphor, important for poetry and visual arts. We conclude with the link between metamorphosis and the notion of rites of passage, and for love stories being told for the pleasure of both author and audience. Pursuit and impossible flight eventually appear as a means for the pursued girl of escaping and yielding, for the pursuer as a means of giving up sexual possession and keeping forever a substitute as the syrinx or the laurel.
\end{abstract}

Borrowing from French photographer Henri Cartier-Bresson the notion of the decisive moment ${ }^{2}$ we intend to show in this article that the ancient authors who narrate metamorphoses mainly seek to capture the fugitive moment when a person or animal is changed from one form to another, and sometimes from one realm of nature to another, most often from human form to animal, plant or watercourse. Artists also try to capture this instant through several devices, for instance Bernini in his well-known sculptural group of Apollo and Daphne. A girl who becomes a tree or a spring, or a young hunter who becomes a bird or another kind of animal are shown in visual arts with different features relevant to her/his

\footnotetext{
${ }^{1}$ I want to express my warm gratitude to the organizers of the conference in Patras and the editors of this volume, particularly Athina Papachrysostomou and Menelaos Christopoulos. My thanks also go to Stephen Rojcewicz and to the anonymous reviewer who corrected my English. Every remaining error is my responsibility.

${ }^{2}$ In 1952, Cartier-Bresson published his book Images à la sauvette, whose English-language edition was entitled The Decisive moment. It included a portfolio of 126 of his photos from the East and the West. The book's cover was drawn by Henri Matisse. For his "philosophical" (so called in the English wikipedia notice on CartierBresson) preface, Cartier-Bresson took his keynote from the 17th century French author Cardinal de Retz : "Il n'y a rien dans ce monde qui n'ait un moment décisif" ("There is nothing in this world that does not have a decisive moment"). Cartier-Bresson applied this to his photographic style. He said : "Photographier : c'est dans un même instant et en une fraction de seconde reconnaître un fait et l'organisation rigoureuse de formes perçues visuellement qui expriment et signifient ce fait" "“To me, photography is the simultaneous recognition, in a fraction of a second, of the significance of an event as well as a precise organization of forms which give that
} 
Françoise Létoublon, decisive moment

previous and new form. ${ }^{3}$

The text corpus chosen for this study consists of the so-called Greek "mythographers,"4

Antoninus Liberalis and Parthenius, collectors of myths living in the first or second century

AD. We chose them because of the amount of myths they tell with a relative stylistic and linguistic unity. Although Antoninus Liberalis seems a little later than Parthenius, we will take him as a point of departure because he is mostly interested in the theme of metamorphosis, and thus seems the most appropriate for a more general study of the poetics of metamorphosis, whereas the main interest of Parthenius is for different forms of passions (see the title Erotica Pathemata). ${ }^{5}$

As mythology consists mainly and fundamentally of narratives, ${ }^{6}$ it is deeply linked to time, to chronology and succession of events. Therefore we think it is important to look very precisely at formal devices that Greek language may use for expressing this relation to time, starting from grammatical features, such as the contrast between imperfect and aorist, emphasizing aspect rather than tense. Later we'll deal with the importance of transitive use, and of active voice as revealing the role of the agent of metamorphosis.

Those aspects have not been studied in previous research on metamorphosis, as far as we know, apart from some insights in Françoise Frontisi’s works, ${ }^{7}$ and the studies of some mythic tales of pursuit and fall by Charles Delattre. ${ }^{8}$

event its proper expression.")

${ }^{3}$ Let us recall that Nicander's work, the model for both Antoninus Liberalis and Ovid's Metamorphoses, was known under the title Heteroioumena, meaning more or less "becoming other", "made other".

${ }^{4}$ For mythography and mythographers, see mainly Henrichs 1987, Dowden 1992, Calame 2004, Higbie 2007, Dowden 2011, Dowden and Livingstone 2011, Bremmer 2011. Antoninus Liberalis and Parthenius are available in good specific modern editions whereas, apart from [Apollodorus], other mythographers are fragmentary (see Fowler 2000, Higbie 2007). Boyle 2007 appears to be a very insightful study on Ovidian poetics of metamorphosis, with several echoes on our theme.

5 "Love passions", Passions d'amour in the French edition (Biraud 2008).

${ }^{6}$ For the meaning of muthos vs logos, see Calame 2004, Fowler 2011, the latter with a thorough study both of uses in ancient texts and of Nestle's influential article.

${ }^{7}$ Frontisi-Ducroux 2000, 2003.

${ }^{8}$ Delattre 2010, 2013. 


\section{The moment of metamorphosis for Antoninus Liberalis}

It may be remarked how often the Greek texts use the aspectual contrast between durative imperfect which shows the frame of the event, and the aorist which expresses the irruption of the metamorphosis into this generally quiet setting, since the metamorphosis usually occurs as the result of some violent attempt, or as a punishment. The imperfect appears then to be the form appropriate for description of the action frame, whereas the perfective aorist refers to the sudden events that occur in the narrative. ${ }^{9}$ Let us look at two instances of this aspectual contrast met in the corpus as defined above. ${ }^{10}$

We choose two short narrative passages from Antoninus Liberalis' Metamorphoses for illustrating this aspectual contrasts:

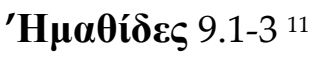

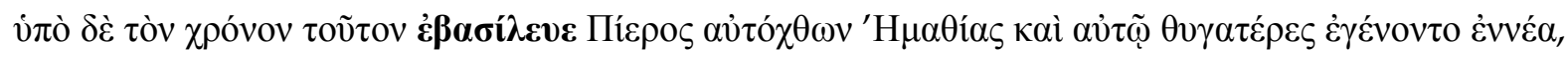

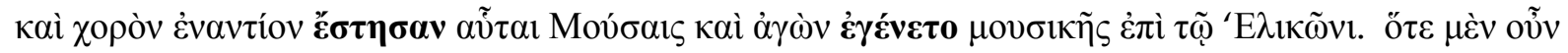

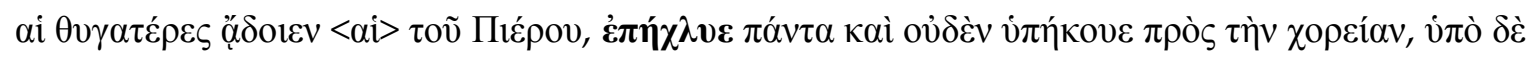

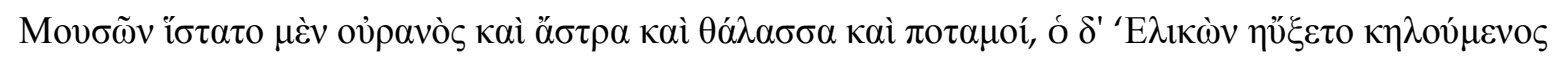

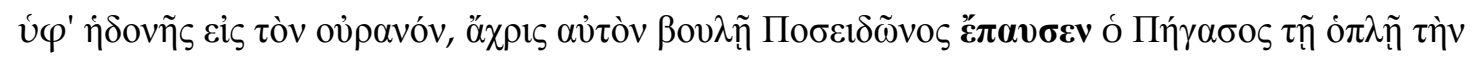

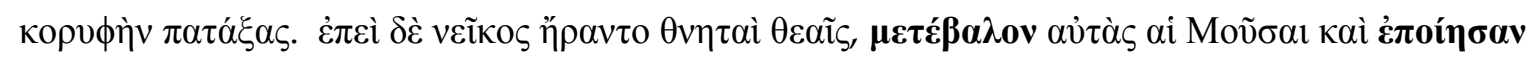

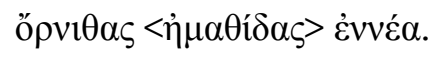

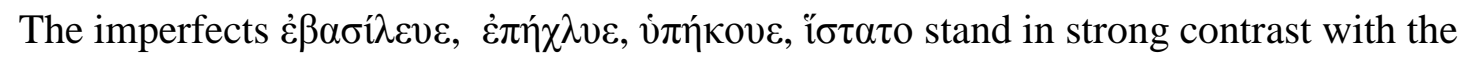

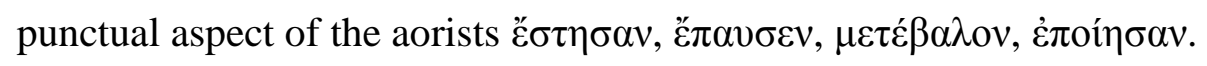

\footnotetext{
9 On aspect (and tense) in Greek morphosyntax, see Ruipérez 1980 (1954), Comrie 1976, Hewson 1997, Hewson 2006, Hewson 2014.

${ }^{10}$ The aorist and imperfect verbal forms to which we intend to draw attention are in bold letters. The opposition between imperfect and aorist sometimes appears rather subjective, and one may sometimes feel that the opposite form could have been used as well.

${ }^{11}$ This story concerns the rivalry between the Muses and Pierides or Emathides, the nine daughters of Pieros, who was then king in Emathia (imperfect $\dot{\varepsilon} \beta \alpha \sigma i \hat{\lambda} \varepsilon v \varepsilon$ ). On the Emathides, see Forbes Irving 1990: 238-39, Hard 2004: 207. The story apparently comes from Nicander, as Antoninus Liberalis himself says. Ovid tells this story in Met. 5.293, suggesting that it gives the aetiology for the use of Pierides as an epithet for the Muses. It could be interesting to study the theme of rivalry with the Muses as a whole, since we know at least two parallels: the Sirens who precipated themselves into the sea after having been defeated in the contest (Bettini- \& Spina 2010),
} 
Françoise Létoublon, decisive moment

The second story chosen for a comment on verbal aspect is called 'A $\mathbf{\lambda} \boldsymbol{\omega} \boldsymbol{\pi} \eta \boldsymbol{\xi}$ ("Fox") 41.8$10:^{12}$

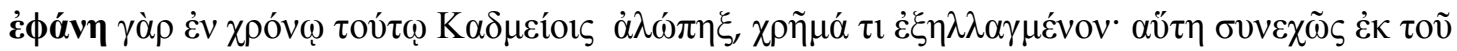

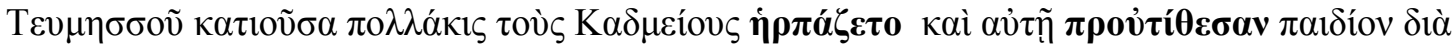

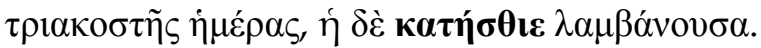

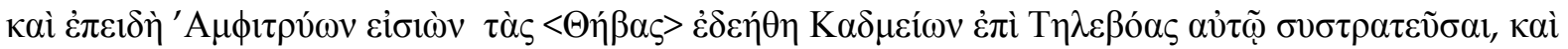

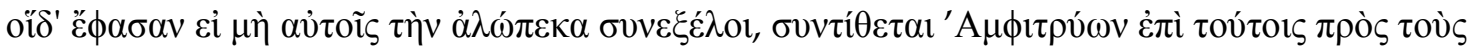

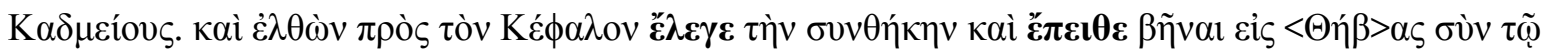

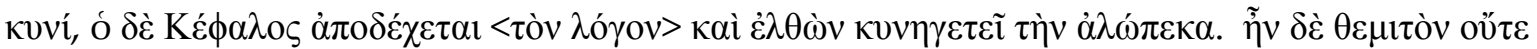

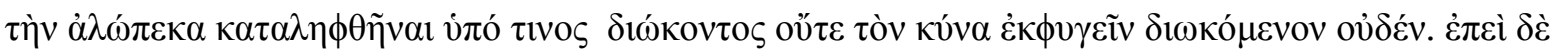

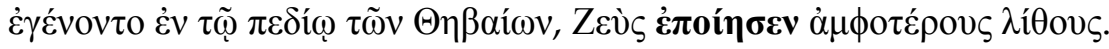

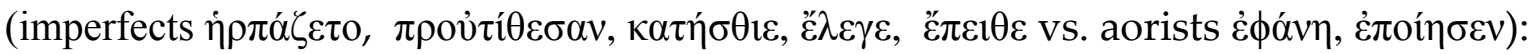

Through the use of aorist forms, the narrator puts the suddenly irrupting event of metamorphosis in evidence. Other formal devices going from grammatical features to symbols may be noticed. We'll come back later to the preceding moment in the tale.

\section{From devices of metamorphosis to its symbols}

The verbs used for describing the metamorphosis are most often transitive (active) verbs: ${ }^{13}$

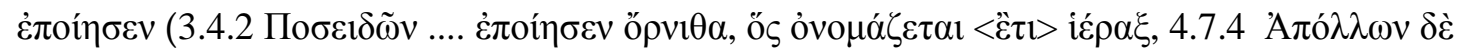

and Thamyris, whom they punished with blindness (Pellizer 2004, Létoublon 2010).

${ }^{12}$ This story - the last one in Antoninus Liberalis' collection - is recorded under the title Alopex, but is better known as Procris and Cephalus' story, particularly because of the version told by Ovid (Met. 7. 763-93) which probably also derives from Nicander. See Pellizer 1981, 42-45, Forbes Irving 1990: 146, 299, Delattre 2010, 2013.

${ }^{13}$ On the notions of transitive (verbs) and transitivity, Conti 2014, on active (verbs), Rutger 2014 : active 


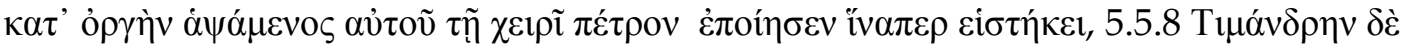

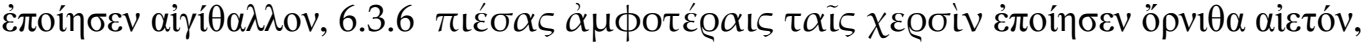

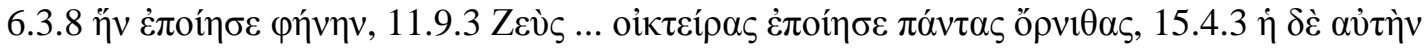

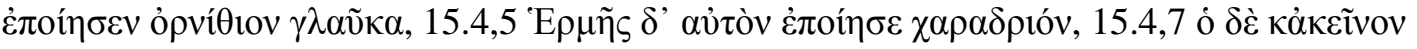

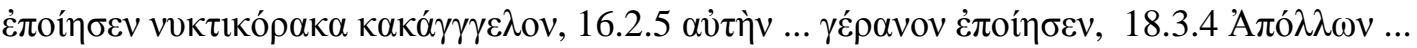

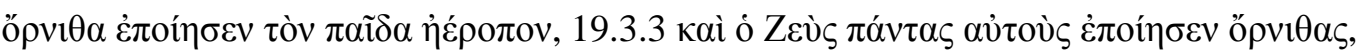

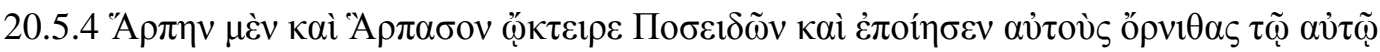

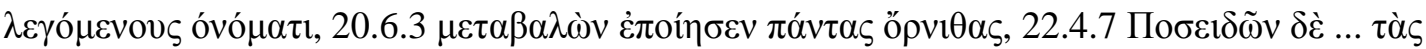

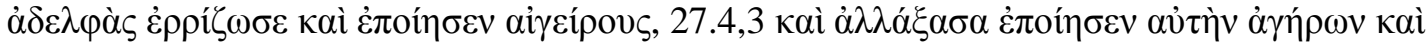

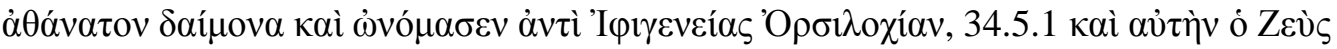

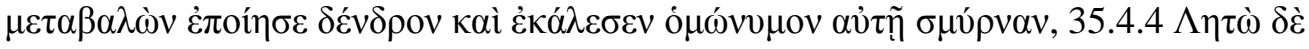

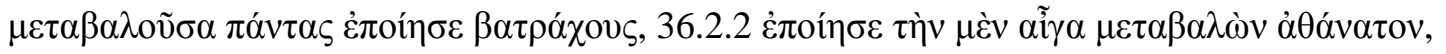

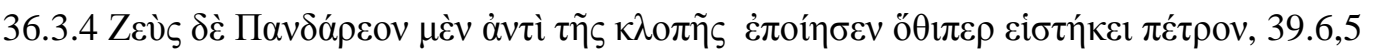

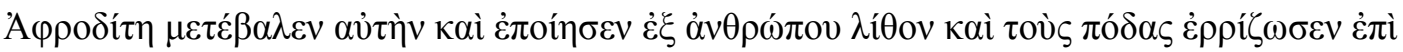

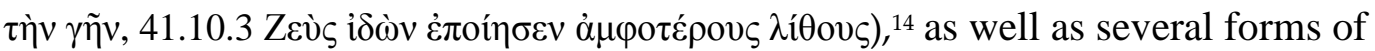

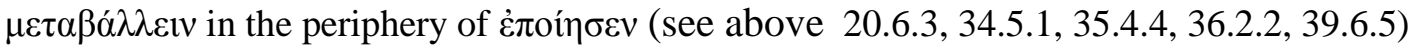

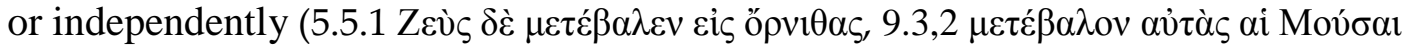

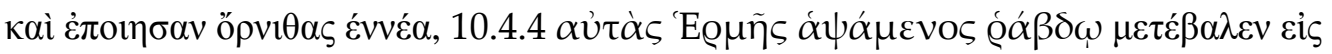

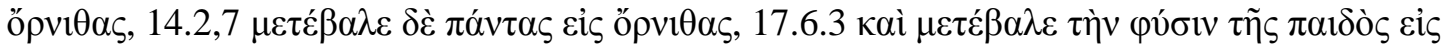

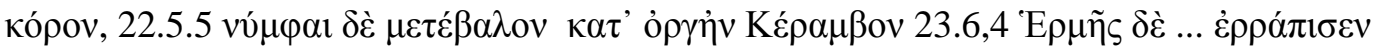

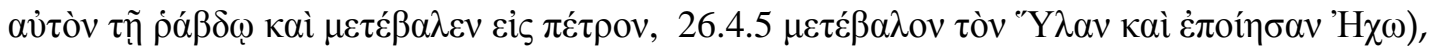
though we also find this verb as intransitive (more or less like changer in French, to

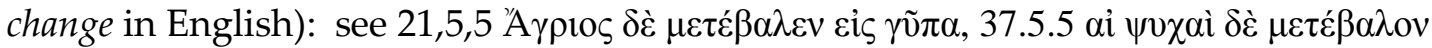

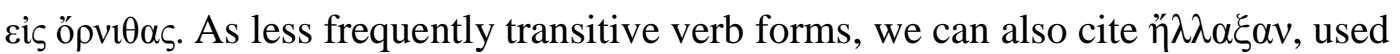

\footnotetext{
transitive verbs are linked to the notion of agent, see below n. 13 .

${ }^{14}$ We did not try to abbeviate this list because swe will later meet several details given here, thus avoiding
} 
Françoise Létoublon, decisive moment

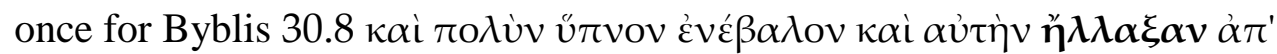

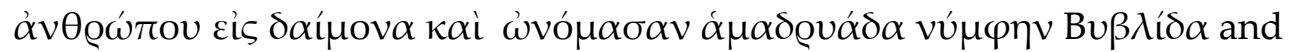

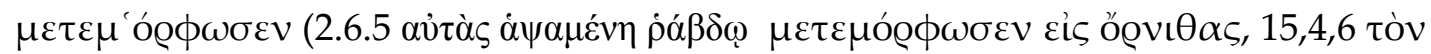

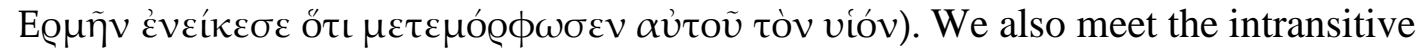

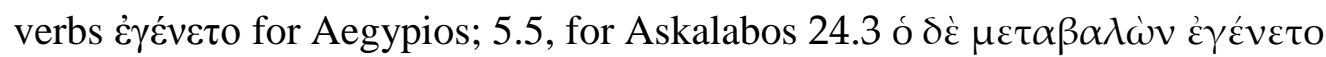

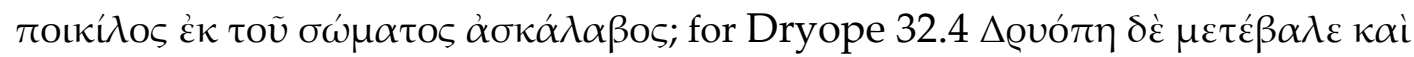

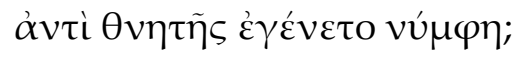

The transitive verbs clearly indicate that someone else is implied other than the metamorphosed person and his/her persecutor, generally a god who feels pity or anger: Zeus, Apollo, Hermes, Leto, Artemis, Athena are thus shown as the agents of the metamorphosis. ${ }^{15}$

\section{The touch and the wand}

In several cases, the active role of a god turns to a touch (expressed in the texts through several uses of the participle $\alpha \dot{\alpha} \alpha \dot{\mu} \boldsymbol{\varepsilon} v \mathbf{o})$, which may be interpreted as a symbolic action. In

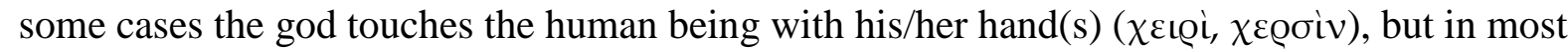
cases, they use explicitly a stick or a magic wand (Gr. $\rho \alpha ́ \beta \delta \omega)$, which well shows how close ancient Greek myths are to fairy tales: ${ }^{16}$

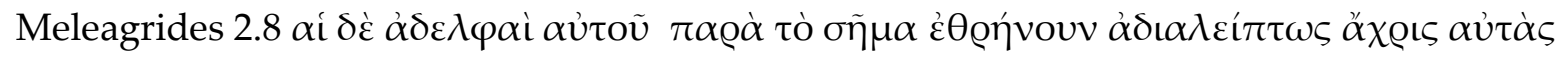

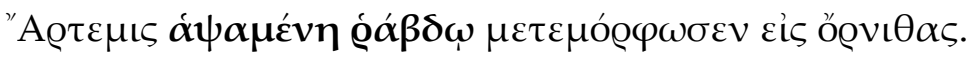

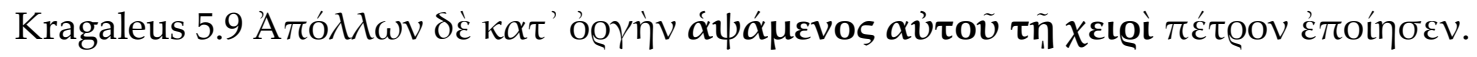

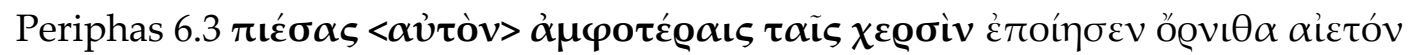

\footnotetext{
repeating the text.

${ }^{15}$ On agency in Greek see Luraghi 2014.

${ }^{16}$ On magic wand in fairy tales, see « Les objets magiques dans les contes » on the website of the Bibliothèque nationale de France (bnf.fr), and the discussion of Bettelheim 1975 by Jack Zipes 2002 and 2006. Particularly Zipes 2002, ch. 6 “On the Use and Abuse of Folk and Fairy Tales with Children.
} 
Françoise Létoublon, decisive moment

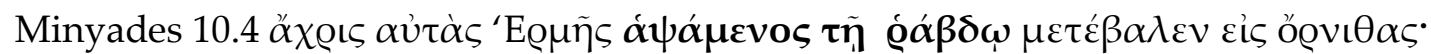

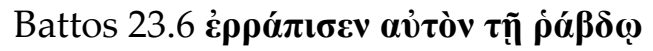

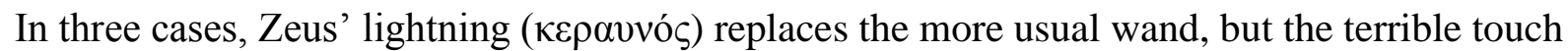
by lightning is avoided by other gods who want to spare their protégés:

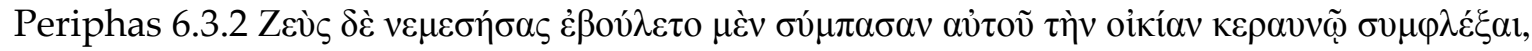

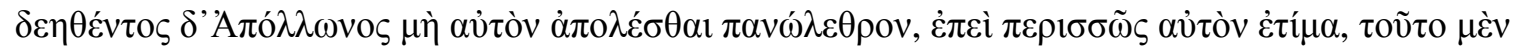
АA

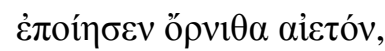

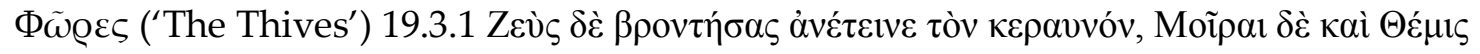

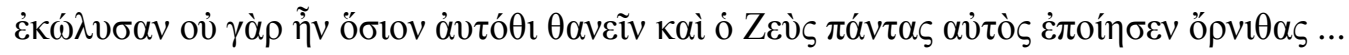

In one case only, for Typhon, Zeus' lightning becomes a lethal weapon :

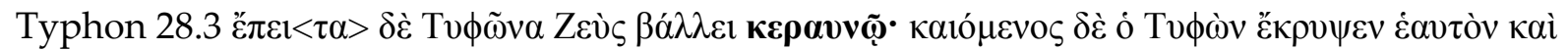

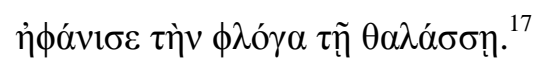

We may also think of the importance of the spear given to Kephalos by Procris in the tale of the Teumessos fox (41), as some engravings for Ovid's Metamorphoses illustrate. ${ }^{18}$

\section{Disappearing}

The metamorphosis is sometimes shown as some incomprehensible change in the world through a succession of events without any visible link: this seems particularly striking in

Bruno Bettelheim's Moralistic Magic Wand" : 179-204.

${ }^{17}$ For Aarne-Thompson and Hansen (2002 : 305-312) the tale of Typhon represents the Greek versions of an international tale, "Ogre Steals Thunder's Instruments" AT 1148B).

${ }^{18}$ Whereas Antoninus Liberalis' narrative is not very evocative. For the spear as a substitute for the magic wand, see for instance the illustration for the medieval manuscript of Othea, or later the Rusconi engraving for Lodovico Dolce's translation of Ovid's Metmamorphoses. See below our analysis 
several cases of disappearance of a human person, usually surrounded by some

metamorphosis in the landscape: ${ }^{19}$ it might seem that the source replaces Lamia as a result of metamorphosis, but nothing is said explicitely.

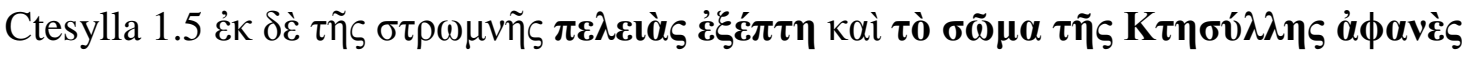

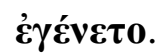

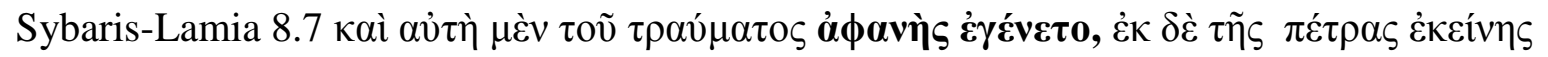

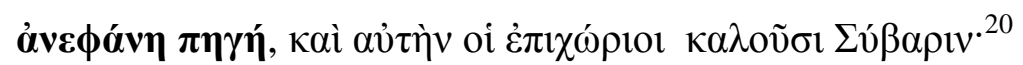

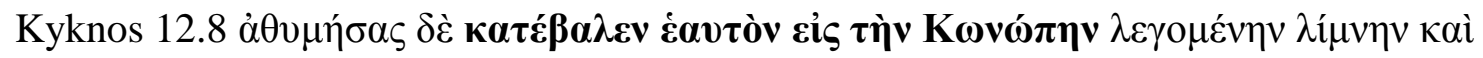

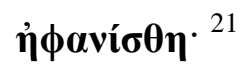

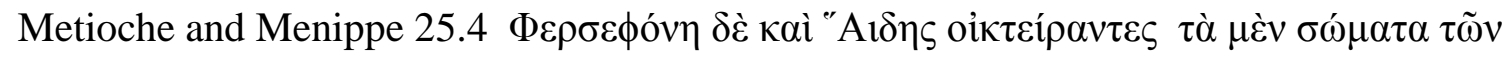

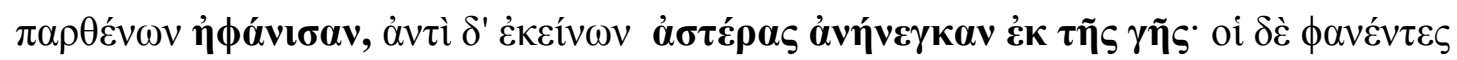

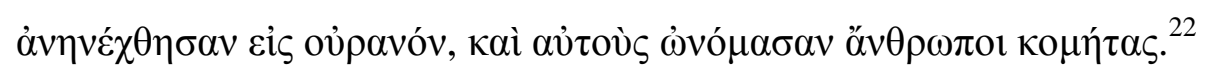

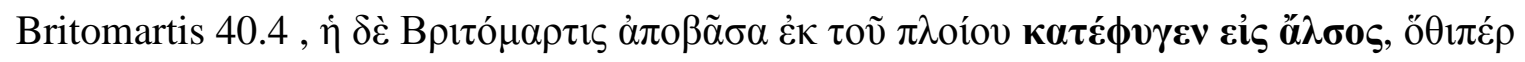

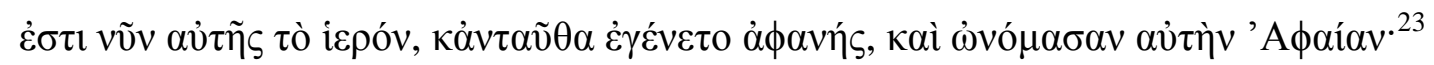

We cannot in this limited space refer to the Latin text in detail, but Antoninus Liberalis demonstrates how much Ovid's Metamorphoses owe to their Greek sources. ${ }^{24}$ His text looks like a prosaic version, without the ornaments of poetry that are so meaningful in Ovid. The

of the 'Instant before'.

${ }^{19}$ We did not mention until now the importance of the landscape: as it is well shown by Cohen 2007 among others, Greeks had no words for referring to the landscape, but all the same it plays an important role in mythology (mountains, caves, trees and bodies of water, particularly).

${ }^{20}$ The story comes from Nicander once more. On Lamia or Sybaris, Forbes Irving (1990:303-4) refers to parallels in Pausanias, Strabo, and Aelian under the name of the "hero of Temesa" who disappears

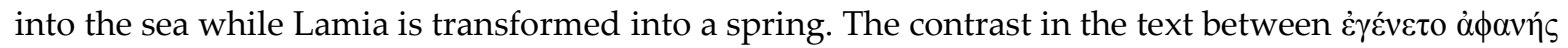
and $\dot{\alpha} v \varepsilon \varphi \alpha ́ v \eta \pi \hat{\gamma} \gamma \eta$ is striking. The aim of the narration appears through the etymogical pun between $\dot{\alpha} \phi \alpha v \eta \dot{\varsigma}$ and

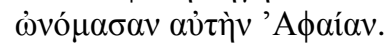

${ }^{21}$ On this Kyknos, son of Apollo, Forbes Irving $1990: 257$ (after the same Nicander; Ovid has a somehow different story from ours).

${ }^{22}$ A tale found only in A. L. (referring to Nicander and Corinna) and Ovid, Met. 13. 685-699. The role of the shuttle (Gr. кєркí) used by the Koronides Virgins for killing themselves is striking.

${ }^{23}$ The story gives the aition for Artemis Aphaia's cult in Aigina, see Forbes Irving $1990: 287$, who refers also to Dictynna in Crete. 
nature of the process of metamorphosis is thus as if denuded of its poetic milieu.

\section{The instant before: pursuit and failing}

If we take into account the time immediately preceding the metamorphosis, we see how

frequently the character who will endure metamorphosis is pursued: another character, most often pushed by an erotic desire frequently through the metaphor of hunting, ${ }^{25}$ tries to touch her/him, in the hope of possession. ${ }^{26}$ The usual topos concerns a girl, more precisely a virgin ( $\pi \alpha \rho \theta \varepsilon \dot{v}$ o $)$ pursued by a would be male raper, but it corresponds to an obsessive theme of the pursuit that cannot touch the target, exemplified in a well-known nightmare told in a Homeric simile, considered by the specialist of the Irrational in Greece as an expression of frustration. ${ }^{27}$ In our mythological corpus, among several examples, the best might be the story of Daphne in Parthenius 15: she was a very good hunter, active in the mountains of Peloponnesos with her dogs, and as she was dear to Artemis, she did not ever miss the target

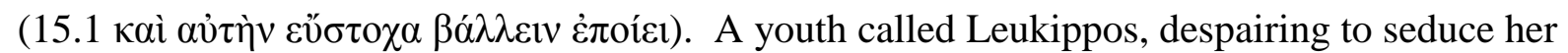
as a man, disguised himself as a woman and took the habit of hunting with her. She

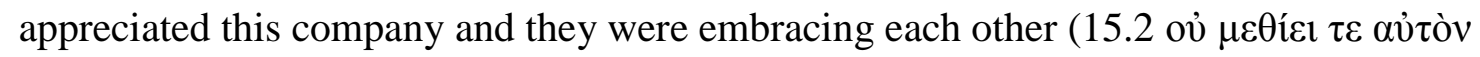

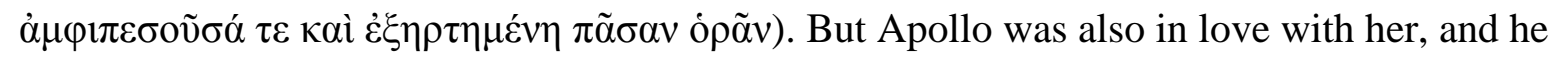
inspired Leukippos to go bathing to the spring with the girls, who snatched his clothes,

\footnotetext{
${ }^{24}$ Lafaye 1971 (1904), Cameron 2004.

${ }^{25}$ On hunting as metaphor, Schnapp 1997, Delattre 2013.

${ }^{26}$ On visual representations of this theme, see Sourvinou-Inwood 1987.

${ }^{27}$ Hom. Il. 22. 199-201

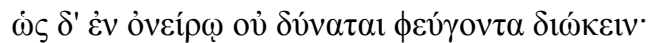

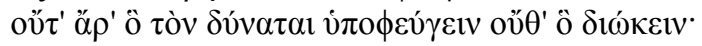

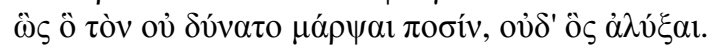

On the whole passage, see the excellent commentary by Richardson 1993, 127. In his famous The Greeks and the Irrational, Dodds quotes this passage as an example of anxiety-dreams: "The poet does not ascribe such nightmares to his heroes, but he knows well what they are like, and makes brilliant use of the experience to 


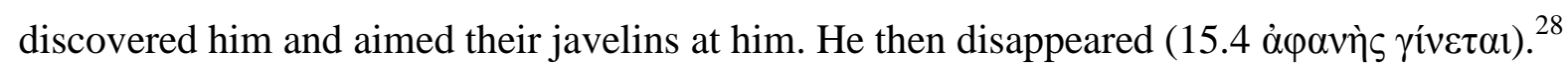
Seeing Apollo about to reach her, Daphne asked Zeus to remove her from the human world

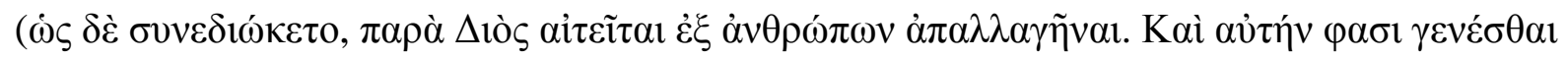

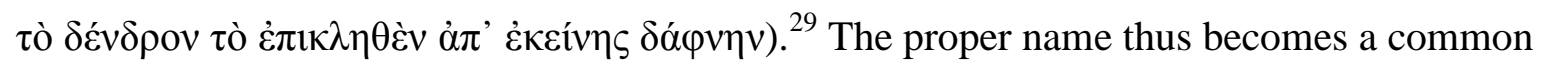
name. $^{30}$

The metamorphosis appears then as a solution for the pursued person for escaping the pursuer, who feels disappointment and frustration, even if he may find some compensation in touching the girl who has been transformed into a tree, for instance: Parthenius leaves this aside but Ovid -whom we quote in translation, since the passage is extensive- narrates it in a very expressive manner.

Phoebus admired and loved the graceful tree, (For still, though changed, her slender form remained) and with his right hand lingering on the trunk he felt her bosom throbbing in the bark. He clung to trunk and branch as though to entwine his form with hers, and fondly kissed the wood that shrank from every kiss. And thus the God; “Although thou canst not be my bride, thou shalt be called my chosen tree, and thy green leaves, O Laurel! shall forever crown my brows, be wreathed around my quiver and my lyre; the Roman heroes shall be crowned with thee, as long processions climb the Capitol and chanting throngs proclaim their victories; and as a faithful warden thou shalt guard the civic crown of oak leaves fixed between thy branches, and before Augustan gates. And as my youthful head is never shorn, so, also, shalt thou ever bear thy leaves unchanging to thy glory." Here the God, Phoebus Apollo, ended his lament, and unto him the Laurel bent her boughs, so lately fashioned; and it seemed to him her graceful nod gave answer to his love. (Met. 1.553-67, transl. Brookes More, etext).

Procris and Kephalos' story in Antoninus Liberalis is interesting in the perspective opened

\footnotetext{
express frustration" (Dodds (1951), 2004, 106).

${ }^{28}$ On disappearing, see the former paragraph.

${ }^{29}$ Daphne's myth is known through several Greek and Latin sources (particularly Statius, Theb. 4.289-290, Pausanias 10.7.8, Ovid, Met. 1.452, 504, 525, 544-6, Hyginus 203). Parthenius' variant is very interesting because of his addition of the transvestite youth Leukippos who arouses Apollo's jealousy.
} 
Françoise Létoublon, decisive moment

with Parthenius' story of Leukippos below: as Kephalos and Procris successively challenge one another, Procris disguises herself as a youth so that she becomes his hunting companion; since he sees that she never misses the target, he desires to possess her javelin. She promises to give it with her dog moreover, in case he grants her his favors. After he accepted, she revealed herself and gave him the javelin and the dog. The pursuit that we see thereafter concerns the dog and the fox: the text says it was impossible for the dog to catch up to the

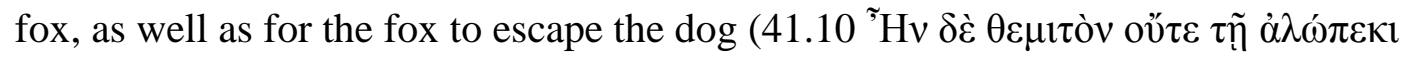

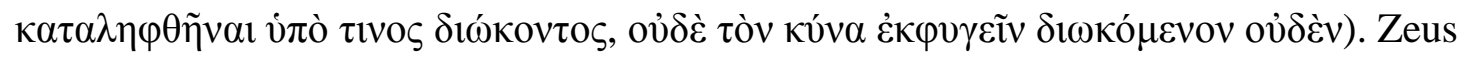
transformed both dog and fox into stones: as if the obsession of pursuit and escaping the pursuer was transmitted from humans to animals, the sole solution for this infernal race being that each participant was fixed forever in his/her position (petrification). ${ }^{31}$

\section{Incestuous loves}

It would be interesting to look into psychoanalytical analysis for the probably very deep roots of this obsessive theme of metamorphoses in Greek myths. I won't develop this general aspect here, ${ }^{32}$ but only mention how often incestuous love occurs in these simple and prosaic narratives, particularly if we add Parthenius of Nicaea to our corpus. ${ }^{33}$

Byblis and Caunus' story is told in Antoninus Liberalis 30, as well as by Parthenius 11 (who quotes two poems relating to them), Conon Dieg. 2, Ovid Met. 9. 441-665. The characters are

\footnotetext{
30 This is true only as far as mythology is concerned of course.

${ }^{31}$ Delattre 2010, 2013. Once again, it would be interesting to compare with the Ovidian version: instead of a mere petrification, he suggests that both animals were transformed into statues rather than stones.

${ }^{32}$ For a general insight on myth and psychoanalysis, see Armstrong 2011, without a special interest in metamorphosis. See also Armstrong 2005, 2013 and the introduction to the volume by Zajko and O'Gorman 2013, 1-17 under the title "Myths and their Receptions: Narrative, Antiquity, and the Unconscious."

${ }^{33}$ On Parthenius' style, see the introduction in Biraud et al. On Eros in Parthenius, Zucker 2008.
} 


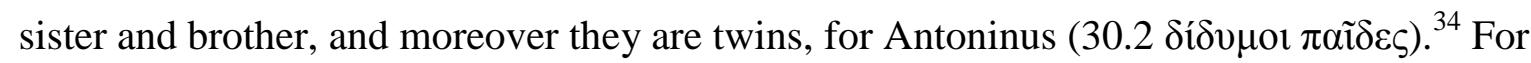

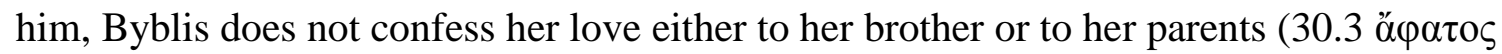

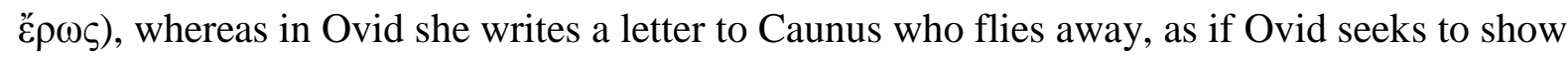
her guilt more clearly. ${ }^{35}$ In Antoninus Liberalis' version, she does not dare to tell her passion to anyone, but she cannot bear it either, deciding to kill herself by precipitating her body from a cliff. ${ }^{36}$ Sympathetic nymphs, however, save her, transforming her into a hamadryad nymph

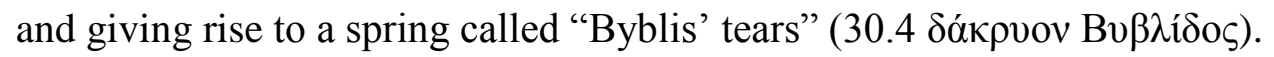

Smyrna (Antoninus Liberalis 34) is parallel to Ovid's Myrrha (Met. 10. 298-518) ${ }^{37}$ She also is in love with her own father (called Theias there, whereas in Ovid he is Kinyras, king of Cyprus). With her nurse's complicity, she manages to secretly gain entry into his father's bed in the dark, until she becomes pregnant, and he discovers her through the stratagem of a torch hidden in the room. ${ }^{38}$ Eventually Theias kills himself, Smyrna gives birth to Adonis and becomes a tree, the liquid flowing from the trunk being assimilated to her tears. ${ }^{39}$ Though shorter than Antoninus Liberalis' corpus, Parthenius ${ }^{40}$ shows eight cases of incestuous loves. ${ }^{41}$ Apart from Byblis and Caunus (Parth. 11), ${ }^{42}$ common to both authors as

\footnotetext{
${ }^{34}$ On twins in Antiquity, see Dasen 2005.

${ }^{35}$ Following the text, some of the Ovidian engravings show Byblis writing her letter.

${ }^{36}$ In other versions, she tries to hang herself to a tree (Parth., Conon).

${ }^{37}$ Forbes Irving thinks this tale is among the oldest ones (1990: 128, 274-7). According to Athenaeus, the difference between both names depends on dialects. The main differences between the different sources are the name of the father, Theias vs Kinyras, the place they are living in, Cyprus vs Mount Liban, and the way Adonis is born from the tree or before his mother's metamorphosis.

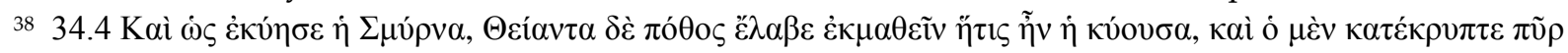

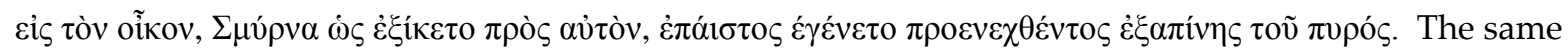
stratagem is met in Ovid's version, cf. also Procris and Kephalos' story in Antoninus Liberalis 41.3.5 'O

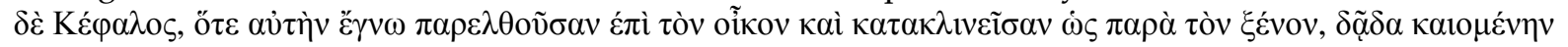

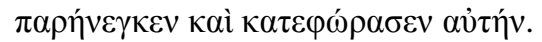

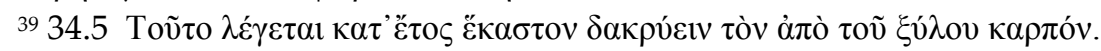

4036 stories in Parthenius, 41 in Antoninus Liberalis.

${ }^{41}$ We do not give the details for those stories. There are four adelphic love stories (Parth. 2 Polymele and her brother Diores, 5 Leukippos, 11 Byblis and Caunus; in 31, the incestuous love concerns Evopis and her brother Troizen, whereas Thymoïtes, Evopis' husband, experiments with another kind of sexual crime, necrophilia). Three tales deal with father-daughter incest (13 Harpalyke with her father Clymenos, 28 Cleite, 33 Assaon whose daughter is there Niobe, with an original version besides the
} 
well as to Latin writers, we find in Parthenius another story of brother and sister, and the most original story, perhaps, that of a mother in love with her son.

Leukippos $^{43}$ (Parth. 5) is in love with his sister whose name is not given. ${ }^{44}$ As he cannot any longer contain his desire, he confesses it to their mother, who complacently helps him to gain satisfaction. ${ }^{45}$ The most surprising detail in this story is that brother and sister seem to have lived happy together for some time, until the girl's fiancé denounced her relation to her father, who strikes his daughter and is eventually killed by his son: Parth. 5.4-5 (Leukippos) kỏk

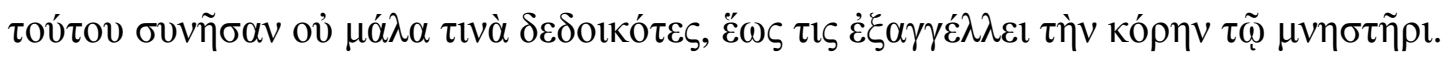

The third main incestuous love story told by Parthenius concerns Periandros' mother, once more a woman we do not know the name of, whereas Periandros is well known from several sources as tyrant of Corinth. For Parthenius, this woman was in love with her son since his

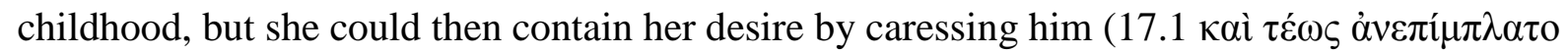

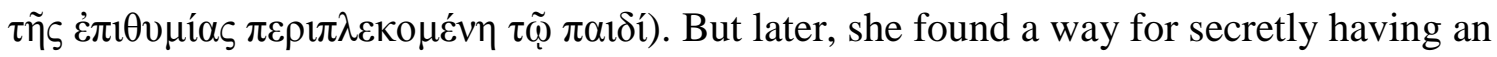
affair with him, letting him believe she was a married woman. The pleasure of love was so strong for Periandros that he wanted to know who she was, and recurred to the device of the

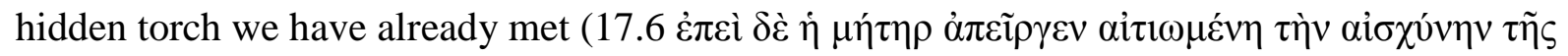

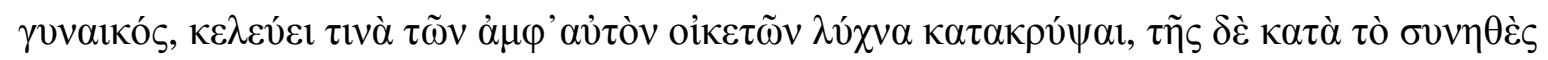

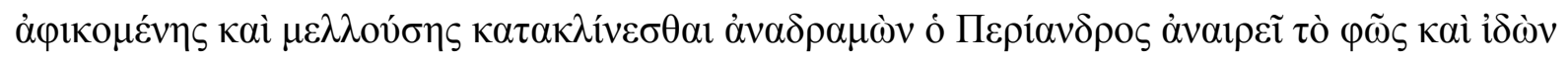

most known versions). The story of Periandros' mother (Parth. 17) tells the sole case of incest between a mother and her son.

42 Parthenius tells two versions of the tale and quotes some pieces of poetry. In the first version, Caunus is first in love with his sister, and he leaves the family home because of this love. In the second one, Byblis is in love with Caunus and tries to talk with him without convincing him (11.3 oi $\delta \dot{\varepsilon} \pi \lambda \varepsilon i ́ o v \varsigma$

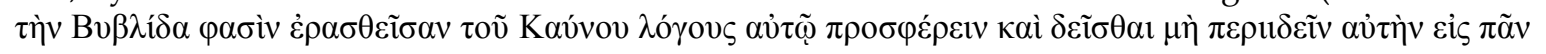

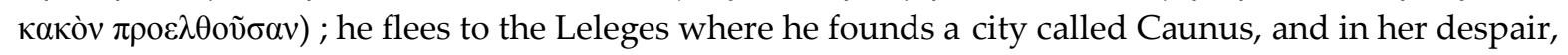

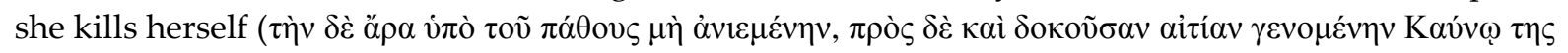

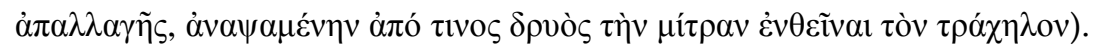

${ }^{43} \mathrm{He}$ is a different character from Leukippos in Antoninus Liberalis quoted above.

44 This is often the case for women in mythology. Let us recall that in Ovid Pygmalion does not give a name to the sculptor's creature. The name is deeply linked to the person (see Salvadore 1987).

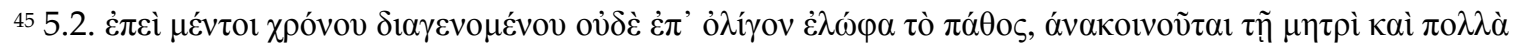




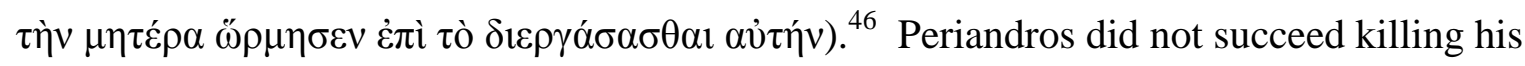

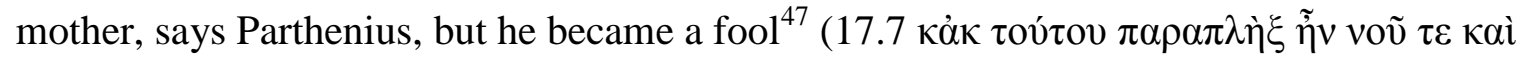

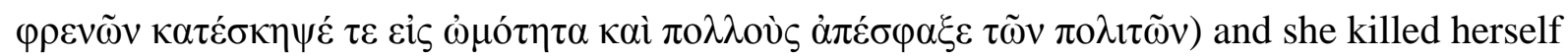
( $\dot{\alpha} v \varepsilon \tilde{\imath} \lambda \varepsilon \dot{\varepsilon} \alpha u \tau \eta ́ v)$.

These cases, with the troubling recurrence of the theme of a kind of complete happiness as long as the incestuous relation remains secret, ${ }^{48}$ and of the hidden torch that reveals the truth, seem to correspond to metamorphosis as a solution for the transgression of the most important prohibitions for mankind.

It seems interesting to think about how Freudian theory would have been more powerful if Freud had used Parthenius' corpus rather than focusing on Sophocles' Oidipous: ${ }^{49}$ as Vernant demonstrated, the latter is seeking for power, having married his mother as a consequence of solving the Sphinx's enigma, rather than as a realization of sexual desire, ${ }^{50}$ whereas Parthenius seems to express the extreme pleasure taken in an incestuous love — apparently consciously in Leukippos' case, unconsciously in Periandros' one.

\section{Metamorphosis and metaphor}

A metamorphosis, summarily defined as a change from one realm of nature to another, is in some way a metaphor re-deployed from a spatial to a temporal frame of reference, from

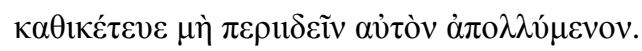

46 The French commentary to Parthenius (Biraud et al. 2008 : 184) notes that another sexual crime is known about Periandros, i. e. necrophilia (Hdt 3.50 and 5.92).

${ }^{47}$ A psychiatrist in Grenoble told me anonymously that he professionally met several cases of foolishness after an incestuous relation between son and mother.

${ }^{48}$ An episode even more explicit than Leukippos and his sister's happiness (Parth. 5.4-5, quoted above) occurs in

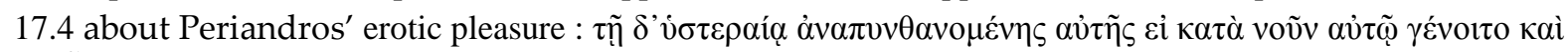

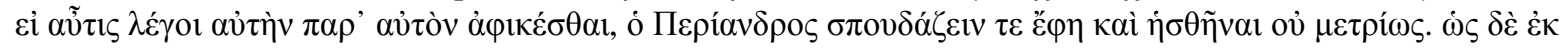

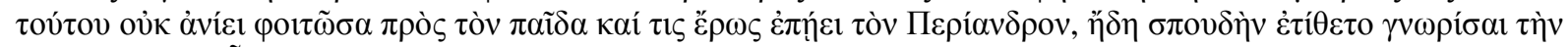

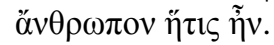

49 On Freud and Sophocles’ Oidipous, see Armstrong 2005, 2011, 2013 quoted above.

50 Vernant's title is eloquent: “CEdipe sans complexe” (“Oidipous without complex”). Vernant 1967. 
before to afterwards. Metamorphosis tells in a timeline what metaphor displays in a single moment of time. Metamorphosis is concerned with evolution whereas metaphor is a kind of equivalence in simultaneity. The tale of Aedon in Antoninus Liberalis is somehow clearer than the very poetic version of Procne and Philomele given by Ovid: as for the Odyssean passage where Penelope compares herself to Aedon or the nightingale ( $\dot{\alpha} \eta \dot{\delta} v),{ }^{51}$ one may think of the complete literal inadequacy between her nocturnal laments and the well-known beauty of the bird's song. ${ }^{52}$ She herself says that she weeps and laments as Aedon who lost her son Itylos (a name close to Itys in Ovid, but nevertheless different): if the Homeric simile refers to Aedon, which in this interpretation is a proper noun, according to our grammatical tradition, it points to an unfortunate woman who killed Itylos, be it voluntarily or not, and parallelism certainly exists. But the context implies that Aedon sings in spring: thus the bird is involved, which means the mother is transformed into a bird, and the word Aedon already is here a common noun. Therefore the Homeric comparison already conceals a metaphor. Antoninus Liberalis is not that subtle, but he also calls both sisters by birds' names, Aedon and Chelidonis ('swallow'), which indicates that metamorphosis has been intended from the beginning.

As fundamentally situated in space, painting and sculpture cannot express metamorphosis

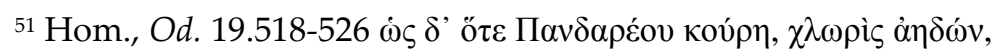

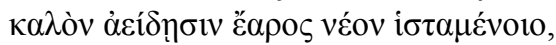

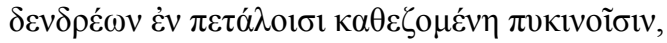

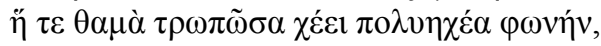

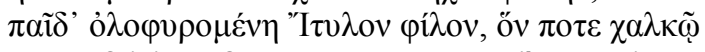

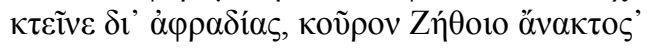

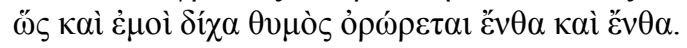

Cp. Od. 20.66 alluding to sisters in the plural form :

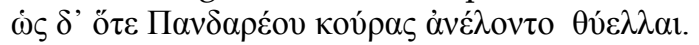

${ }^{52}$ Létoublon 2004 on the myths of Aedon, Philomele and Procne in Homer, Antoninus Liberalis, and

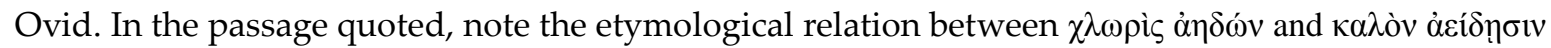

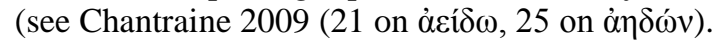


except through contiguity, ${ }^{53}$ for instance by taking into account the moment that immediately precedes or follows it, the instance where the character undergoes the beginning of the change. The Daphne by Bernini has still a human face and body, but her arms and fingers are already being transformed into branches and palm leaves. Actaeon is often shown as a man with deer antlers. On an Etruscan black-figures hydria of around 530 B.C. we can see several characters who are partly transformed: a human diver as well as dolphins who still have human legs. The Centaurs (half men and horses) and the god Pan (a human figure with goat feet) could embody an ongoing or stopped metamorphosis. Narrative literature, as an art of time, is able to tell how forms change, a coach becoming a pumpkin, a beast becoming a handsome young man, a man becoming a deer, or a girl becoming a tree or a spring... Françoise Frontisi-Ducroux explains this as a «goût vorace de la différence », « désir du différent, de l'étrange, de l'étranger, de l'ailleurs; désir de fusion avec l'autre ». ${ }^{54}$ In the same time, let us recall that girls who are pursued, be it by Pan, who does not look very appealing, or by Apollo who is often taken as a model of masculine beauty, generally refuse this fusion and prefer complete metamorphosis or disappearance rather than such a union with this lover.

In conclusion, we would like to open up the question of the meaning of metamorphosis, especially for young girls and youths, by linking it to the notion of "rites of passage" in anthropology and sociology. ${ }^{55}$ Among those rites, several societies, ancient and modern, put in relief the difficulty of passing from childhood to adolescence, and then from adolescence to adulthood. ${ }^{56}$ Its reality was demonstrated for Antiquity through the study of several literary

\footnotetext{
${ }^{53}$ On metamorphosis in art, Sharrock 1996.

54 Frontisi-Ducroux 2003. 277.

55 The notion was discovered and analyzed by Arnold Van Gennep 1909 (see Van Gennep 1960 in English). It won success through such œuvres as Victor Turner 1997. We organised an international conference in Grenoble for the centenary of Van Gennep's book (edited by Philippe Hameau, Christian Abry, Françoise Létoublon 2010). The concern of rites of passage in antiquity has been studied by Padilla 1999.

${ }^{56}$ Scars appear sometimes as marks of the inititation rite that a character had endured as a youth: this might hold good for Odysseus' scar on the thigh (Od. 19. 385-98) and for Orestes' scar near the eyebrow, if we follow
} 
genres and texts, ${ }^{57}$ and we may even now hold firmly enough that the whole genre of Greek 'ideal' novel constitutes a kind of answer to this question: how young girls and youths may go through this period of their life, what tests or trials are they supposed to succeed in, encountering one another, falling in love, separations, and so on, ${ }^{58}$ the existing rituals being interpreted as some kind of symbolic transposition of actual trials. ${ }^{59}$ Some myths or mythological episodes that deal with transvestites (Achilles among Lycomedes' daughters in the Epic Cycle, Leukippos in Parthenius above) could receive an explanation as rites of passage. $^{60}$

In his various works on the subject, Ken Dowden put aside myths, epic and novel genres. ${ }^{61}$ In my "mythological paradigms" paper, ${ }^{62}$ I show how often, in the idealistic novels written in Greek during the first centuries of Roman era, the characters themselves tell some myths for a paradigmatic use. ${ }^{63}$ If in myths metamorphosis appears as a means for escaping the rape by the dangerous pursuer, narrating the myths might incarnate the symbolic transposition of the rite of passage: for instance in Leucippe and Clitophon, the youth hears a

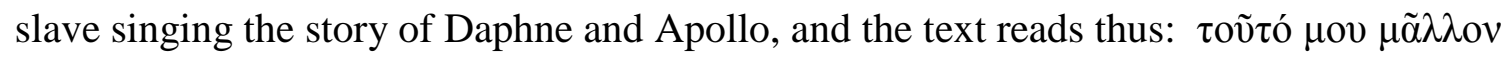

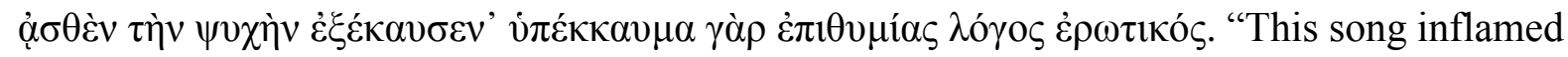
my soul all the more, for erotic stories fuel the appetite." (1.5.5) Thus hearing (or reading?)

\footnotetext{
Euripides' Electra (Létoublon 2010).

57 Probably first with tragedy and the character of Orestes, see for instance Vidal-Naquet 1986 (1981), Padilla 1999.

${ }^{58}$ On those lieux communs in Greek novels, Létoublon 1993.

${ }^{59}$ Those rituals are different for girls and youths, Dowden 1999, 2011, Lalanne 2006, 2010. The corespondences between myths and rituals are not easy to understand (Dowden 2011: 489-92 about Iphigeneia and arkteia).

${ }^{60}$ On Achilles, Dowden 2011: 493.

${ }^{61}$ Particularly Dowden 1989, 1999.

${ }^{62}$ Létoublon 2013.

${ }^{63}$ The passages quoted are the following: [Longus], Daphnis and Chloe 1.23.3 (concerning Phatta, implied in a poetry and music contest, but including an allusion to a pursuit and flight tale concerning Pitys and Pan), 2.34-37

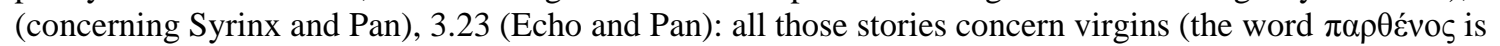
constantly recurring) who are pursued by Pan and escape him through metamorphosis : Pitys as a pine-tree, Syrinx as the eponymous music instrument, Echo as the natural eponymous phenomenon. Another paradigmatic myth is told in book 2.6 about Eros in Philetas' garden. There are also examples of the device in Achilles Tatius, Leucippe and Clitophon 1.16-18, 5.3.4-8, 5.5.2-9 (Tereus, the lark and the nightingale), 8.6.3-10 (the myth of Syrinx, parallel to Daphnis and Chloe, receives here the charge of proving Leucippe's virginity), and 8.12 (Styx's water, as a very sophistic test of virtue for the secondary character of Melite. The aetiology of the myth
} 
love stories 'fuel' erotic desire and pulsions, which might be a powerful impulse for telling them. $^{64}$

What about the pursuer in those myths of pursuit? Let us recall that he is often a god, and not the most awful of them; if Pan actually appears often in these myths, Zeus, Poseidon and the very handsome Apollo also appear very frequently. We quoted Apollo's feeling of frustration in Ovid's version of Daphne. In the novels, Pan's frustration is even more characteristic, especially as he realizes that Syrinx disappeared in the bulrushes. ${ }^{65}$ But afterwards, he feels a kind of pleasure in making an instrument with the cut bulrushes, with a striking image of dismembering and reconstructing the body, ${ }^{66}$ and the music he produces becomes the metaphor of her respiration. ${ }^{67}$ The whole passage shows the instrument as a substitute for the girl. ${ }^{68}$ We think it possible to establish a parallel with the psychoanalytic notion of sublimation, and to generalize this conclusion to other cases where a god feels frustrated in his erotic impulse when the person he was pursuing either disappears or undergoes metamorphosis. ${ }^{69}$ Therefore the frustrated pursuer is himself transformed somehow in this adventure. In the mythographers' corpus, the cases of girls enduring metamorphosis after a sexually deviated adventure like that of Byblis and Smyrna might show such a sublimation: their tears are flowing forever in the form of a spring or of myrrh.

\footnotetext{
is the story of Rhodopis and Euthynicos, who both swore they would never 'know Aphrodite').

${ }^{64}$ Zajko and O'Gorman (2013, 13-14) well emphasize the importance of desire in both the author and the audience or readers.

${ }^{65}$ [Longus], Daphnis and Chloe 8.6.9 "He thought the maid had been changed into the reeds and wept that he had cut her, supposing his beloved had been slashed".

${ }^{66}$ Daphnis and Chloe 8.6.10 "Gathering up the severed bits of reed as if they were the limbs of her body and joining them together as a single body, he held in his hands the cut ends of the reeds and kissed them as if they were the maiden's wounds. He groaned as he put his lover's lips to them and so breathed into the flutes from above as he kissed them". This passage seems very close to Ovid's description of the metamorphosis of Daphne into laurel, as Zajko and O'Gorman 2013, 8 analyzed it: "The description lingers over each body part as it is translated into the parts of a tree which seems the most appropriate for it. Feet as roots, hair as leaves, et cetera. In one way the transformation is made to seem appropriate and 'natural' ; this raises the question of whether a transformation takes place at all. For Apollo's sexual desire does not seem to be diminished; indeed, he persists in his fondling of the nymph/tree, who can no longer run away" (see above $\S 4$ ).

67 "His breath flowed through the narrow reed passages and made flutelike sounds : the syrinx had a voice".

68 See Zajko and O'Gorman 2013, 8: "The theme of metamorphosis itself de-naturalizes the process of human development and change, as the characters in the poem transform into flowers, animals, and trees".
} 
Those story show that the relation of both would be raper and pursued girl to their own body is seen as a problem. Zajko and O'Gorman commenting Daphne's metamorphose in Ovid say it better than I could: ${ }^{70}$ "The relationship between mind and body is centrally important here but it is also highly problematic : Ovid does not help the observer, who is left to surmise some inner state by means of physical phenomena. It is through the observer's interpretative choices that these phenomena may become signs of internal life, or, to use a psychoanalytic term, symptoms".

As Harris says, metamorphosis places the character "between two deaths": neither dying nor still living as a human person. Transformed into an unmoving tree, a still more motionless stone, a flowing watercourse or a flying bird, she will stay forever the symbol of the impossible flight. Daphne becoming as the laurel the symbol of Apollo who pursued her is the symbol of both the refuse of being touched by him and of accepting it. ${ }^{71}$

\footnotetext{
${ }^{69}$ Harris 2013, 258-60, recurrs to Lacan for analyzing Daphne's impossible flight as a Lacanian jouissance.

70 Zajko and O'Gorman 2013, 9.

${ }^{71}$ Harris 2013.
} 